\title{
PENDEKATAN PERSON-CENTERED DALAM MENANGANI BODY SHAMING PADA WANITA
}

\author{
Oleh: Desi Alawiyah ${ }^{1}$ \\ ${ }^{1}$ Institut Agama Islam Muhammadiyah Sinjai, \\ Jl. Sultan Hasanuddin, No. 20 Balangnipa, Sinjai \\ E-Mail: alawiyahdesi2@gmail.com,Tlp.:085334057620
}

\begin{abstract}
Abstrak
Menginjak fase pubertas remaja mengalami fase peruahan salah satu perubahan fisik. Beberapa kasus yang dialami oleh remaja berupa kekerasan non veral. Perubahan fisik menjadi bahan ejekan, seperti terlalu tinggi, terlalu pendek, terlalu gemuk, terlalu kurus, berkulit coklat, dan lain sebagainya. Komentar soal tubuh yang dianggap tidak sesuai keyakinan kecantikan dapat membuat seseorang merasa kurang peraya diri. Kemajuan teknologi pada era ini memudahkan individu dalam mengakses informasi dari segala media. Selain memudahkan juga menimbulkan permasalahan perbandingan dari individu satu dengan lainnya. Body shaming seagai salah satu kasus yang mudah sekali terjadi tanpa disadari oleh setiap orang. Body shaming adalah bentuk dari tindakan mengomentari fisik, penampilan, atau citra diri seseorang. Pendekatan person-centered memberikan bantuan berupa meningkatkan kualitas hubungan antara konselor dan klien (conditions for therapeutic change). Konselor membentuk kembali ideal self dan real self dari Individu tersebut.
\end{abstract}

\section{Kata Kunci: Person-Centered, Body Shaming}

\section{PENDAHULUAN}

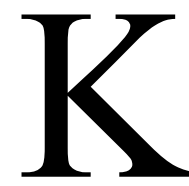

emajuan teknologi pada era ini menghadirkan kemudahan dalam mengakses informasi dari berbagai media, baik melalui televisi maupun gadget. Hal ini kemudian juga perspektif dan sikap masyarakat terhadap sesuatu, termasuk standarisasi tubuh ideal, baik bagi laki-laki maupun perempuan. Beberapa kasus yang membuat sebagian masyarakat cukup resah akhirakhir ini adalah terjadinya kekerasan yang menimbulkan korban bukan hanya secara fisik tetapi juga secara psikis khususnya dikalangan remaja.

Seringkali masa pubertas membuat para remaja secara psikis merasa terbebani, sehingga mereka memiliki kecenderungan labil dan emosi yang tidak menentu. Tidak jarang pula mereka kehilangan rasa percaya diri karena perubahan bentuk tubuhnya. Menurut Strandbu dan Kvalem dalam penelitian Sakinah bahwa tubuh ideal pada wanita digambarkan dengan tubuh yang cenderung kurus, berlekuk, kuat, dan sehat sedangkan tubuh ideal laki-laki adalah yang ramping, berotot dan sehat. Tidak jarang jika pada akhirnya hal ini menuntun seorang perempuan pada tekanan yang lebih besar terkait persepsi tubuhnya. 
Agama dinilai memiliki peran dalam membentuk konsep kecantikan. Dalam agama Islam, konsep kecantikan sering dikaitkan dengan citra tubuh yang tertutup sebagaimana dalam QS AlA'raaf/7: 26

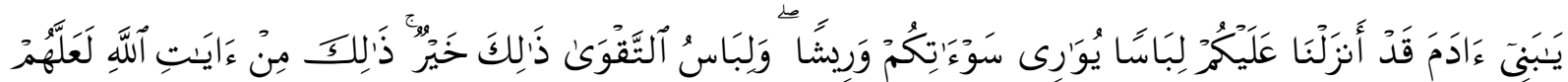

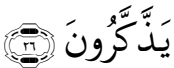

Terjemahnya:

Hai anak Adam, sesungguhnya kami telah menurunkan kepadamu pakaian untuk menutup auratmu dan pakaian indah untuk perhiasan. Dan pakaian takwa itulah yang paling baik, yang demikian itu adalah sebahagian dari tanda-tanda kekuasaan Allah, mudah-mudahan mereka selalu ingat.

Sehubungan dengan hal tersebut, Nabi Muhammad saw bersabda bahwa "Sesungguhnya Allah tidak melihat kepada bentuk rupa dan harta kalian, tapi ia melihat hati dan amal kalian" (HR.Muslim, Ahmad dan Ibnu Majah). Berbanding terbalik dengan hadis di atas, saat ini beberapa kasus yang dialami remaja saat menginjak fase pubertas adalah berupa kekerasan verbal. Perubahan fisik menjadi bahan ejekan teman korban, baik itu karena terlalu tinggi, terlalu pendek, terlalu gemuk, terlalu kurus, berkulit coklat, dan lain sebagainya. Komentar soal tubuh yang dianggap tidak sesuai keyakinan kecantikan dapat mengarah pada body shaming. Body shaming adalah bentuk dari tindakan mengomentari fisik, penampilan, atau citra diri seseorang.

Sebagaimana yang telah kita ketahui, bahwa kekerasan terbagi menjadi dua, yatu kekerasan fisik dan kekerasan psikis (verbal). Tidak dapat dipungkiri bahwa saat ini sedang marak adanya kasus bullying mengenai body shaming baik itu secara langsung maupun yang sering kita jumpai di media sosial seperti di laman instagram, facebook, youtube dan lain sebagainya. Kondisi tersebut dapat menyebabkan korban body shaming mengalami trauma psikis seperti tidak percaya diri, depresi dan stress. Oleh karena itu, dalam upaya menangani hal tersebut maka sangat penting peran bimbingan dan konseling Islam dalam mengkaji permasalahan ini. Karena seseorang menginginkan kebutuhan untuk aktualisasi diri dan kebutuhan untuk dicintai dan dihargai oleh orang lain. Selain itu, pemerintah juga telah mengeluarkan peraturan bagi pelaku penghinaan atau body shaming di media sosial dapat dijerat dengan pasal 27 ayat 3 dan pasal 45 ayat 3 UU No. 11 tahun 2008 dengan ancaman pidana penjara paling lama empat tahun dan/atau denda maksimal Rp. 750 juta. 


\section{HASIL DAN PEMABAHASAN}

\section{Formulasi Penanganan Masalah}

Tulisan ini disusun berdasarkan dua rumusan masalah, antara lain: a) Bagaimana dampak yang ditimbulkan akibat body shaming? dan b) Bagaimana formulasi penanganan masalah akibat adanya body shaming? Setelah menuliskan kedua rumusan masalah tersebut, maka berikut pemaparannya.

Adanya citra tubuh memungkinkan seseorang untuk membandingkan keadaan dirinya dengan orang lain dan menimbulkan rasa malu terhadap tubuh, yang sering disebut dengan istilah body shame. Body shame merupakan penilaian individu akan tubuhnya yang memunculkan perasaan bahwa tubuhnya memalukan yang disebabkan penilaian dirinya dan orang lain terhadap bentuk tubuh ideal tidak sesuai dengan tubuhnya. Namun saat ini, juga seringkali secara langsung teman sebaya menjadikan penampilan fisik sebagai bahan ejekan terhadap individu di dalam kelompoknya. Body shaming merupakan suatu bentuk kekerasan verbal emosional yang sering tidak disadari oleh pelakunya karena umumnya dianggap wajar.

Kasus body shaming yang mengarah pada tubuh, wajah dan penampilan dapat menyebabkan tekanan-tekanan tertentu terhadap seseorang khususnya pada wanita. Maraknya kasus tersebut dapat melunturkan kepercayaan diri korban dan menggiring korban untuk membenci diri sendiri. Selain itu, korban body shaming akan cenderung mengalami gangguan makan, merasa rendah diri, mengalami depresi serta gangguan mood. Obsesi terhadap kecantikan dan citra tubuh dianggap berkontribusi negatif, olehnya itu diperlukan penanganan khusus dalam kasus ini.

Kemampuan merasakan apa yang dirasakan oleh orang lain (empati) sangat diperlukan oleh profesi konselor. Bahkan kemampuan ini adalah kemampuan dasar yang dibutuhkan untuk menangani kasus bullying dalam hal ini body shaming. Adapun formulasi penanganan masalah bagi pelaku body shaming salah satunya yaitu mengadakan suatu kampanye sosial untuk mengajak masyarakat menyadari bahwa secara sadar maupun tidak sadar, dengan maksud baik maupun tidak baik, bahwa perilaku body shaming merupakan bentuk kekerasan yang memberikan dampak buruk bagi para korbannya, khususnya para remaja wanita yang belum memiliki kematangan psikologis yang cukup (labil), sehingga kekerasan ini harus di hentikan. Jika ditinjau dalam kajian Islam, bullying sama dengan al-baghyu yaitu berbuat sewenang-wenang, berbuat zalim dan menganiaya orang lain. Nabi saw, bersabda; yang artinya: "Ada dua dosa yang akan didahulukan Allah siksanya di dunia ini yaitu al-baghyu dan durhaka kepada orang tua." (H.R. Tarmidzi, Bukhari, dan Thabrani).

Selain hal tersebut di atas, adanya formulasi penanganan masalah untuk korban body shaming dalam bimbingan dan konseling Islam juga perlu ditindak lanjuti salah satunya dengan menggunakan pendekatan person-centered. Person-centered sebagai model pendekatan dalam konseling merupakan hasil pemikiran Carl R. Rogers. Pendekatan Rogerian tidak hanya berisi pertanyaan-pertanyaan teori tentang kepribadian dan psikoterapi, tetapi juga suatu pendekatan, suatu orientasi atau pandangan 
tentang kehidupan. Pendekatan tersebut menitikberatkan kemampuan dan tanggung jawab klien untuk mengenali cara pengidentifikasian dan cara menghadapi realitas secara lebih akurat. Semakin baik klien mengenali dirinya, maka semakin besar kemampuan mereka mengidentifikasi perilaku yang paling tepat untuk dirinya.

\section{Korelasi Pendekatan Person-Centered Terhadap Kasus Body Shaming}

Pendekatan person-centered memandang manusia secara positif bahwa manusia memiliki suatu kecenderungan kearah berfungsi penuh. Dalam konteks hubungan konseling, klien mengalami perasaan-perasaan yang sebelumnya diingkari. Klien mengaktualkan potensi dan bergerak ke arah peningkatan kesadaran, spontanitas, kepercayaan kepada diri, dan keterarahan.

Peran dan fungsi konselor dalam pendekatan person-centered meliputi kongruen atau keaslian (klien tidak lagi berpura-pura dalam kehidupannya), penerimaan tanpa syarat, pemahaman yang empatik dan akurat. Dalam pendekatan person-centered memiliki beberapa teknik, antara lain: mendengar aktif, mengulang kembali, memperjelas, menyimpulkan, bertanya, menginterprestasi, mengkonfrontasi, merefleksikan perasaan, memberi dukungan, berempati, menfasilitasi, memulai, menentukan tujuan, mengevaluasi, memberikan umpan balik, menjaga, mendekatkan diri, mencontoh model dan mengakhiri. Adapun tahap-tahap konseling dalam pendekatan person-centered yaitu proses konseling yang fleksibel dan sangat tergantung pada proses komunikasi antara konselor dan klien. Penerimaan tanpa syarat konselor terhadap klien. Konselor menunjukkan sikap empati terhadap klien. Konselor harus dapat meyakinkan konseli dengan sikap dan perilakunya yang menunjukkan kualitas konselor.

Adapun korelasi terhadap pendekatan person-centered dengan kasus body shaming terdapat pada karakteristik individu korban body shaming dalam pendekatan ini adalah terjadinya kesenjangan antara real self dan ideal self yang disertai dengan kecemasan. Individu dalam pendekatan personcentered dilihat sebagai sosok yang bertindak untuk memenuhi kebutuhan pokoknya, yaitu kebutuhan untuk aktualisasi diri dan kebutuhan untuk dicintai dan dihargai oleh orang lain. Dengan adanya penerimaan diri dan kepercayaan diri pada korban body shaming, maka hal tersebut akan membawanya pada kehidupan yang lebih terarah dan tidak membalas bullying dengan bullying.

\section{Pendapat-Pendapat yang Mendukung Argumentasi}

Dalam tulisan ini, penulis mengangkat kasus tentang body shaming yang saat ini marak diperbincangkan baik di dunia nyata maupun di dunia maya (social media). Penulis menggunakan pendekatan person-centered dalam penanganan masalah body shaming tersebut karena pendekatan ini ditujukan pada individu, kelompok, keluarga dan masyarakat. Carl R. Rogers mengemukakan bahwa manusia adalah pribadi-pribadi yang memiliki potensi untuk memecahkan permasalahannya sendiri. Willis juga mengatakan bahwa person-centered sering pula disebut sebagai psikoterapi non-directive 
yang merupakan metode perawatan psikis yang dilakukan dengan cara berdialog dengan klien agar tercapai gambaran antara ideal self (diri ideal) dengan actual self (diri sebenarnya).

Individu yang dikatakan sehat adalah yang dirinya dapat berkembang penuh (the fully functioning self) dan dapat mengalami proses hidupnya tanpa hambatan. Adapun individu yang telah mencapai "fully functioning" ditandai dengan keterbukaan pada pengalaman, menghidupi setiap peristiwa secara penuh, dan mempercayai pertimbangan dan pemilihan sendiri. Sedangkan individu mengalami masalah jika ada ketidakseimbangan/ ketidakseuain antara pengalaman organismik dan self yang menyebabkan individu merasa dirinya rapuh. Peran konselor pada pendekatan person-centered lebih mengarah kepada bagaimana sikap konselor bukan pada teknik-tekniknya, hal tersebut berfungsi membangun suasana pelayanan konseling yang mendukung pertumbuhan klien serta berfungsi membangun hubungan yang membantu, dimana klien akan mengalami kebebasan yang diperlukan untuk mengekplorasi kehidupannya.

Dalam pandangan Rogers, konselor lebih banyak berperan sebagai partner klien dalam memecahkan masalahnya. Dalam konteks bimbingan dan konseling, konselor lebih banyak memberikan kesempatan kepada klien untuk mengungkapkan segala permasalahan, perasaan dan persepsinya dan konselor merefleksikan segala yang diungkapkan oleh klien. Agar peran ini dapat dipertahankan dan tujuan konseling dapat dicapai, maka konselor perlu menciptakan iklim atau kondisi yang mampu menumbuhkan hubungan konseling. Kondisi konseling ini menurut Rogers satu keharusan dan cukup memadai untuk pertumbuhan, sehingga dia menyebutnya sebagai necessary dan sufficient conditions for therapeutic change. Kondisi-kondisi yang perlu diciptakan itu adalah sebagai berikut:

1. Konselor dan klien berada dalam hubungan psikologis.

2. Klien adalah orang yang mengalami kecemasan, penderitaan dan ketidakseimbangan.

3. Konselor adalah benar-benar dirinya sejati dalam berhubungan dengan klien.

4. Konselor merasa atau menunjukkan unconditional positive regard untuk klien.

5. Konselor menunjukkan adanya rasa empati dan memahami tentang kerangka acuan klien dan memberitahukan pemahamannya kepada klien.

6. Klien menyadari (setidaknya pada tingkat minimal) usaha konselor yang menunjukkan sikap empatik berkomunikasi dan unconditioning positive regard kepada klien.

Dalam kacamata keilmuan Yusuf Qardhawi, tindakan-tindakan kekerasan (fisik dan psikis) termasuk body shaming tidak akan berkembang apabila memenuhi beberapa aspek, yaitu:

1. Toleransi, pemahaman akan nilai-nilai toleransi harus menjadi prioritas dalam bermasyarakat. Apabila terjadi perbedaan maka dialog musyawarah harus dikedepankan, hal ini disebabkan apabila nilai-nilai toleransi atau saling menghargai dilenyapkan atau ditinggalkan, maka kehidupan harmonis hanyalah utopia semata. 
2. Mendudukan manusia sesuai kodratnya sebagai manusia. Islam, dengan sumber figur utama yakni Nabi Muhammad saw, telah banyak mencontohkan dalam kepribadian beliau, bagaimana memposisikan manusia sebagai mana semestinya.

3. Tidak membalas perbuatan radikal baik secara fisik maupun maya, dengan kata lain pelaku radikal, apabila dia sempat berbuat tindak kekerasan baik secara fisik maupun verbal atau digital, hendaklah ditarik keranah diskusi yang bernuansa damai. Ini bersesuaian dengan makna islam itu sendiri.

4. Meninggalkan perkara saling hujat dan saling cela hingga menjatuhkan ucapan yang tidak layak.

Dengan menggunakan pendekatan person-centeres, korban body shaming akan mulai menerima real self dengan tidak memaksakan diri untuk menjadi ideal self . Karena dalam Islam cantik yang sesungguhnya dilihat dari akhlak seseorang bukan dari paras dan bentuk tubuh, sebagaimana yang telah dijelaskan dalam hadis sebelumnya. Korban body shaming juga membutukan aktualisasi diri dan kebutuhan untuk dihargai bagaimanapun kondisi fisiknya karena sejatinya tidak ada manusia yang sempurna, masing-masing dari kita memiliki kekurangan.

\section{KESIMPULAN}

Tindakan body shaming terjadi di sekitar kita di kalangan masyarakat pada semua status sosial, di dunia nyata maupun di dunia maya melalui media sosial, terutama instagram sebagai media yang fokus pada photo sharing para penggunanya. Para selebriti juga tidak luput dari body shaming, misalnya Prilly Latuconsina yang dikomentari karena dianggap memiliki ukuran tubuh gemuk dan pendek untuk seorang figur publik, dan baru-baru ini terjadi kepada artis Dian Nitami yang hidungnya dikomentari jelek oleh salah satu netizen sampai sang suami Anjasmara melaporkan netizen tersebut ke polisi. Ini menunjukkan bahwa apapun bentuk tubuh selalu ada yang nampak kurang di mata orang lain, kemudian secara sadar ataupun tidak yang bersangkutan melakukan body shaming terhadap orang lain yang dianggapnya memiliki kekurangan. Melalui beberapa peristiwa tersebut, maka inilah alasan mengapa penulis mengangkat kasus body shaming yang biasanya tanpa kita sadari sudah lumrah terjadi dan dinilai wajar untuk dilakukan.

Dengan adanya bimbingan dan konseling Islam melalui bantuan seorang konselor melalui pendekatan person-centered, korban body shaming mendapatkan semangat dan motivasi untuk kembali percaya diri dengan apa adanya dirinya (real self). Dalam hal ini konselor menunjukkan sikap empati terhadap korban body shaming agar tidak merasa asing dengan keadaanya yang dinilai tidak ideal self. Perlu ditekankan juga, bahwa dalam kehidupan kita harus selalu intropeksi diri, dengan menganggap bahwa selain orang lain, kita juga punya kekurangan. 


\section{DAFTAR PUSTAKA}

Chaplin, J.P. (2005). Kamus Lengkap Psikologi. Jakarta: Rajawali Press.

Chasanah, Uswatun. (2018). Pendekatan Person-Centered Berbasis Nilai Unggah-Ungguh dalam Pelayanan BK Di Sekolah. Prosiding SNBK. Vol. 2 No.1.

Corey, Geral. (2006). Teori dan Praktek Konseling dan Psikoterapiterjemahan E. Koswara. Bandung : PT. Refika Aditama.

Gibson, Robert L. Marianne H. Mitchell. (2011). Bimbingan dan Konseling. Yogyakarta: Pustaka Pelajar.

Lestari. Rini Larassati, Laily Puji Astuti. (2017). Peningkatan Percaya Diri Siswa Menggunakan Layanan Bimbingan Kelompok Melalui Pendekatan Person-Centered. Prosiding Seminar Bimbingan dan Konseling. Vol. 1, No. 1.

Lubis, Namora Lumongga. (2011). Memahami Dasar-Dasar Konseling dalam Teori dan Praktik. Jakarta: Kencana.

Maharani, Rizki. (2018). Penerapan Falsafah Narimo Ing Pandum dalam Pendekatan PersonCentered untuk Mengatasi Depresi Remaja. Prosiding SNBK. Vol. 2 No. 1.

Melliana S, Annastasia. (2013). Menjelajah Tubuh: Perempuan dan Mitos Kecantikan. Yogyakarta: LkiS.

Sakinah. (2018). "Ini Bukan Lelucon”: Body Shaming, Citra Tubuh, Dampak dan Cara Mengatasinya. Jurnal Emik. Vol. 1 No. 1.

Salahudin, Anas. (2010). Bimbingan dan Konseling. Bandung: Pustaka Setia.

Widagdo, Haidi Hajar. (2017). Kekerasan dalam Dunia Digital (Tinjauan Islam Terhadap Perubahan Gaya Radikal di Era Digital ). Jural Fikri. Vol. 2, No. 2. 